\title{
Corpo-espaço organização e funcionamento de uma noção discursiva
}

\author{
Body-space: organization and functioning of a discursive notion \\ Marisa Martins GAMA-KHALIL \\ Universidade Federal de Uberlândia (UFU) \\ https://orcid.org/0000-0003-2236-4334 \\ Nilton MILANEZ \\ Universidade Estadual de Feira de Santana (UEFS) \\ https://orcid.org/0000-0002-1669-0304
}

\begin{abstract}
RESUMO: O artigo apresenta o delineamento da noção corpo-espaço, fundamentada por intermédio de quatro elementos constituintes, ancorada nos estudos discursivos de Michel Foucault: a questão da materialidade do discurso; sua configuração enquanto unidade discursiva; sua composição utópica e heterotópica; e sua interface com a realidade e o real. Para a realização do batimento entre a noção teórica de corpo-espaço e o movimento de análise, elegemos duas narrativas, uma literária e outra audiovisual: o conto "O gato preto", de Edgar Allan Poe, publicado em 1843, e o filme dele decorrente, "The Black Cat", de 1934, dirigido por Edgar G. Ulmer.
\end{abstract}

PALAVRAS-CHAVE: Corpo-espaço. Real. Heterotopias. Materialidades. Michel Foucault.

ABSTRACT: This article presents the outile for the body-space notion based through four constitutive elements supported by the Discurisve Studies on Michel Foucault: the question of the discursive materiality; its configuration as a discursive unity; its utopic and heterotopic composition; and its interface with reality and real. Targeting the confrontation between the body-space theoric notion and its analysis mouvement, we selected two narratives, one literary and the other audiovisual: the tale The Black Cat, by Edgar Allan Poe, published in 1843, and the movie inspired by it, The Black Cat, directed by Edgar G. Ulmer in 1934.

KEYWORDS: Body-space. Real. Heterotopias. Materialities. Michel Foucault.

\section{Cena em três movimentos}

Os movimentos discursivos do que compreendemos, hoje, como corpo-espaço atravessaram alguns anos no tempo e transformaram em aliança os laços que abraçavam nossos grupos de pesquisa. O Laboratório de Estudos do Discurso e do Corpo e o Grupo de Pesquisas em Espacialidades Artísticas constelavam juntos em suas pesquisas, considerando o corpo e o espaço naquilo tudo que eles têm de ficcional, simbólico e insólito na busca de fazer girar a realidade de nossos objetos de estudo. Para nós, as audiovisualidades e as narrativas em cena nos domínios do discurso sempre foram o modo de existência do recheio das materialidades corporais e espaciais. E assim as 
entendíamos, naquele início, como objetos de discurso que se associavam em agrupamento um ao outro. Líamos, víamos e ouvíamos em adição o corpo e o espaço. Estávamos na nossa fase do e, que nos deixava felizes, mas com o sentimento teórico, às vezes, da oscilação, de um lado, pelo corpo, de outro, pelo espaço. Apresentava-se ali um escalonamento que fazia emergir mais intensamente o corpo ou mais largamente o espaço. Isso criava um desnível discursivo que nos incomodava, uma sombra insólita que iluminava de acordo com o objeto de estudo a incorporação teórica.

Nessa primeira fase, diante da efervescência dos encontros de nossos grupos de pesquisa e do intercâmbio em nossas publicações, foram os resultados de nossos próprios trabalhos que identificaram esse empuxo entre corpo e espaço, o que nos demonstrava se tratar de ir além das aglutinações dos temas.

O fenômeno discursivo apontava para o fato de que esse 'e' não correspondia à realidade dos fatos que víamos surgir diante de nossos olhos. Essa visada inicial nos levou a compreender que não estávamos apenas lado a lado. Escutamos, então, atentamente os objetos de discurso e ouvimos em alto e bom som que estávamos um com o outro, o corpo no espaço com o espaço no corpo. Aliviados, entendemos que aquilo que nossos trabalhos mostravam se tratava de uma dobra, um estava contido no outro, o outro estava no um; o corpo se situa em um dado espaço, mas ele é também um espaço. Acreditávamos, ainda, que o corpo com o espaço se amalgamava ao invés de se ligar, ou seja, começamos a compreender que não se tratava de uma simples relação, entretanto de uma fusão, de uma constituição imbricada. A fragilidade do laço dava lugar ao plissado, criando inúmeras possibilidades com essa dobradura discursiva. Enfrentávamos ali o período do desdobramento constitutivo dos objetos uns sobre os outros. A intensidade teórica chegava a seu nível passional, aqueles grandes arroubos que apenas os apaixonados conhecem.

A voracidade que come o corpo por dentro naquele momento que faz o espaço desaparecer acendeu a luz vermelha da nossa paixão teórica. Olhando um nos olhos do outro sem medo de nos petrificarmos, revíamos aquilo que já nos parecia tão certo, tão estável e, por isso mesmo, afastando-se das intempéries climáticas entre espacialidade e corporalidade. Na revisitação do longo desses mais de dez anos, damos de encontro com um lugar súbito que nos mostra a singularidade de um modo heterogêneo, porém único de materialização. Não se tratava de e apenas. Não se organizava em paralelo com a dobra. Corpo-espaço passaria, assim, a ser grafado com hífen, pois a estrada ensinava que o fenômeno tinha a ver com um circuito. Não se podia, de fato, determinar onde ele 
começava, até onde ele ia, quais regiões ocupava, quais rugosidades exigia. $\mathrm{O}$ circuito do corpo-espaço configura, para nós, um tipo de destino da fluidez das materialidades, nas quais as hierarquias se desmontam, o continuum e o estável se desfazem. No campo do dizível, o corpo-espaço é uno, no campo das enunciabilidades, o corpo-espaço está para a unidade do discurso na sua heterogeneidade, afinal a unidade se compõe do diverso. O corpo-espaço enquanto campo e objeto é, incontrolavelmente, uma região de indiscernibilidade. Queremos é mostrar o indiscernível dessa questão que por tanto tempo relegou o espaço a um domínio inferior, menor, em relação à posição que ocupa o corpo na formatação das narrativas e das audiovisualidades. Não há, portanto, uma jurisdição de maior ou menor espectro, de mais profunda ou rasa razão, com uma biologia mais bem formada ou mal formada. O que queremos verificar, demonstrar e firmar é que há uma circuitação na nervura e no nó constante do corpo em território, e do território no corpo.

Daqui, portanto, dessa circuitação corpóreo-espacial, buscamos de forma mais metodológica estabelecer os granulados que concorrem nessas materialidades. Encontramos esses granos do circuito corpo-espaço tilintando no arcabouço teórico de Michel Foucault, de quem fomos seguindo as pistas, os risos discretos e as indicações de seus dedos longos até chegarmos aqui.

O corpo-espaço da personagem na ficção do insólito é constituído por seu teor heterotópico: a materialidade corporal se desdobra em corpos duplos, vários corpos, corpos inesperados, dilatados segundo um espaço que lhe é ao mesmo tempo interior e exterior, presente, passado e futuro. Ao evidenciarmos o corpo-espaço, o domínio da ficção do insólito se amplia no contra-espaço foucaultiano, quando o espaço comum se metamorfoseia em um espaço inesperado e insólito, no espaço liso e estriado deleuziano; quando o corpo acelera marcas do monstruoso, da deformação, da depravação, da anormalidade segundo a ordem social. (GAMA-KHALIL; MILANEZ, 2018, p. 7)

\section{Quatro pontos constituintes da noção de corpo-espaço}

Passaremos, dessa feita, a apresentar os fundamentos teóricos da noção corpoespaço por intermédio de quatro pontos constituintes deflagrados pelos estudos discursivos foucaultianos: a questão da materialidade do discurso; sua configuração enquanto unidade discursiva; sua composição utópica e heterotópica; e sua interface com a realidade o real. Ao lado dessas constituições, demonstraremos o funcionamento dessas condições a partir da ficção de Edgar Allan Poe, mais especificamente, seu conto "O gato preto", publicado em 1843, e o filme dele decorrente, "The Black Cat", de 1934, dirigido por Edgar G. Ulmer. 
No início do conto o narrador oferece ao leitor um discurso caracterizado por incertezas, tão ao gosto do fantástico, porquanto afirma que irá contar a sua história, que é ao mesmo tempo familiar e estranha - infamiliar, inquietante. Ainda que declare não esperar que o seu leitor confie no seu relato, afirma que não é louco. Tem-se, pois, um corpo-espaço cindido entre a sanidade e a loucura a partir da narração de uma história sobre um gato que após a sua morte tem seu corpo-espaço ressurgido e reinventado no corpo-espaço de outro gato quase tão idêntico ao seu, a não ser por uma mancha branca no peito com o formato pavoroso de uma forca, indicando sugestivamente a possibilidade de uma forca que porá fim à vida do corpo-espaço do narrador por ter emparedado o corpo-espaço de sua esposa. O fantástico da narração deve-se ao fato de ser o corpo-espaço do segundo gato que delata o emparedamento do corpo-espaço da mulher.

A narrativa do filme The Black Cat se passa na Hungria, tomada como um lugar inóspito, porque compreendida fora do eixo América do Norte e Europa clássica. O deslocamento do espaço geográfico já introduz o semblante do fantástico e do horrorífico. Os corpos que ali se plantam são o de Joan e Peter Allison, recém-casados, em lua-de-mel naquele país. Dessa feita, é o discurso sobre o matrimônio que será colocado em jogo. A integridade matrimonial será abalada por Vitus Werdgast, interpretado por Bela Lugosi, conhecido ator do filme "Dracula", de 1931. O casal travará contato com Vitus na cabine do trem que os leva à Hungria. Chegando ao destino, tomam um carro juntos e sofrem um acidente. Desorientados aceitam abrigar-se na casa modernista de Poelzig, interpretado por Boris Karloff, mundialmente reconhecido pelo filme "Frankenstein", amigo de Vitus. A casa de Poelzig, e sua engenharia de emparedamento, separam os corpos em núpcias, fazendo emergir o corpo-espaço em uma narrativa de tensão, sombras, rituais diabólicos entre portas, paredes, uma virgindade vigiada e atitudes perversas. Apesar dessa descrição, o mais importante não é a narrativa de "The Black Cat", mas o modo como as audiovisualidades desencadeiam o corpo-espaço proibido, o suplício do corpo-espaço emparedado e o controle de uma moral marcada no corpo e inflada pelo espaço, uma moral cristã do corpo-espaço.

\section{As materialidades do discurso}

Entendemos por materialidade as "condições de existência" (FOUCAULT, 2008, p. 43) para o discurso. Como podemos compreender, então as marcas e traços que 
dão contorno à existência histórica das materialidades? Acreditamos que o primeiro dos elementos que cabe ser levado em conta é o aparecimento de certa materialidade e o modo como ela se desenvolve no suporte que o acolhe. Isso é essencial.

Sob essa perspectiva, a materialidade do discurso literário no que tange à ordem da língua e a materialidade imagética/sonora para o discurso das audiovisualidades (MILANEZ, 2019) passam a ser um tipo de "superfícies primeiras de sua emergência" (FOUCAULT, 2008, p. 46) para o surgimento do corpo-espaço em um dado suporte. O suporte, seja ele livro seja filme, tomará os contornos de materialidade, apenas se investigarmos e trouxermos à baila as condições históricas que deram visibilidade àquele suporte e seu material. Neste caso, a verificação do material linguístico-literário e das audiovisualidades fará aparecer a espessura histórica do objeto, atribuindo-lhe seu caráter discursivo.

Um segundo elemento se centraria no estabelecimento da relação da materialidade com o campo de seu objeto. Isso significa falar que o campo do objeto precisa ser nomeado, ou seja, cabe discorrer sobre o domínio social de um dado conhecimento no qual ele aparece, quer dizer, no campo das sexualidades, das práticas políticas, das manifestações religiosas, para citarmos as mais abrangentes.

Depois disso, um terceiro elemento consiste em elevar esses domínios a uma descrição dos encadeamentos linguísticos-literários e das conexões nas audiovisualidades, o que consequentemente desembocará, em um quarto e último elemento, nos aspectos analíticos sobre o objeto de estudo. Este tópico, portanto, é um aspecto metodológico para se enfrentar as dimensões do corpo-espaço.

Em resumo, seguimos uma trajetória que integra as materialidades do corpoespaço em suporte, nomeando seus domínios e descrevendo suas materialidades, para apresentar, por fim, a espessura histórica de cada objeto a partir de ecos da cultura de nossas narrativas e audiovisualidades. Seguimos, enfim, com alguns modos de mobilização desses elementos que alicerçam o corpo-espaço, suas posições possíveis e seu engendramento nos modos de enunciar o corpóreo-geográfico enquanto instâncias do discurso.

O conto foi publicado pela primeira vez na revista semanal United States Saturday Post (Saturday Evening Post) em 19 de agosto de 1843 com o título original The black cat. O título do conto sugere índices de entendimento da história que começará a ser narrada/lida. A nomeação "O gato preto" tem como centro um corpoespaço que em muitas culturas é considerado símbolo de azar, mau agouro. Desde a 
Idade Média é associado às bruxas e, em muitos casos, como sendo a própria presentificação do diabo. Quando o narrador descreve o gato pela primeira vez ressalta a sua inteligência e remete "à antiga crença popular que olhava todos os gatos pretos como feiticeiras disfarçadas" (POE, 2001, p. 293). O nome do gato é mais um elemento que entra para corroborar com o enlace da rede de sentidos sugerida com a centralidade do corpo-espaço de um gato preto, uma vez que ele se chama Plutão. De acordo com a astrologia analítica, Plutão é o nome do "príncipe das trevas, [...] o símbolos das profundezas de nossas trevas interiores, ligadas à noite original da alma" (CHEVALIER; GHEERBRANT, 1990, p. 725), sentidos esses que parecem anunciar o que se desenrola ao longo do enredo, uma vez que o corpo-espaço de Plutão pode ser associado à degradação do corpo-espaço do narrador-protagonista, é o corpo-espaço duplicado do gato que insiste em não morrer que incita os devaneios da alma e à falibilidade e consequente morte do corpo-espaço do seu dono. Acresce-se ao título do conto o nome do autor, o qual figurava junto ao título, já que Edgar Allan Poe, no ano de publicação do conto, tinha um nome consolidado como autor de contos de terror, fato que colabora para a intensificação de uma pré-leitura da atmosfera de terror que poderá ser descortinada ao longo do conto. O enredo do conto confirmará esses índices que o leitor encontra espalhados antes da leitura propriamente dita, porque o narrador, envolvido de modo nefasto pelo poder do álcool e dos corpos-espaços do(s) gato(s), se verá imerso em espaços soturnos, como o da taverna e o do porão onde emparedará o corpo-espaço de sua mulher. A forca, anunciada sobrenaturalmente no corpo-espaço do gato, será o destino do corpo-espaço do narrador.

Os créditos iniciais de um filme costumam funcionar como uma síntese das audiovisualidades num todo, apresentando um campo bem delimitado de antecipação dos discursos e saberes que estão por vir. Esse tipo de modalidade discursiva vai ter lugar durante a introdução de um quadro com o título do filme, em The Black, seguido de uma sequência de audiovisualidades que fixam grades sobre as condições de possibilidade do filme enquanto irrupção histórica.

Os quadros introdutórios trazem os nomes de Boris Karloff e Bela Lugosi, colocando o filme em um campo de memória das monstruosidades. Mas não se trata de um campo qualquer. A designação de seus corpos, a imagem da letra de seus nomes na abertura está encadeada com os personagens de Frankenstein e de Drácula. Desse modo, suas nomeações constroem um corpo para seus nomes. Seus nomes nos créditos corporificam os monstros que aparecerão ao longo das audiovisualidades do filme. 
Portanto, os créditos não trazem apenas os atores a título de apresentação, delimitam o corpo-espaço monstruoso no entrelaçamento dos nomes à história cinematográfica que a precede e os domínios do suporte fílmico daquelas imagens em movimento. Desse modo, como em uma cascata discursiva, outros campos fertilizam o escopo da abjeção daquelas audiovisualidades.

Não podemos deixar de apontar que às visualidades a que nos referimos, ou seja, o olhar com sua força escópica concentrando a rede de sentidos do corpo, se soma o espaço sonoro que compreende e encerra a construção de um discurso insólito. Estamos falando da "Sonata em Si Menor" de Franz Liszt, que também se inicia com a exposição dos créditos. Como esse espaço sonoro vai compor sentido com o corpo visual que descrevemos? Para tanto, o campo de memória compartilhado sobre a dramaticidade dessa composição faz efeito como um marcato, uma crescente energia musical que se desenvolve sobre os títulos e nomes, atribuindo um desdobramento fixa à materialidade discursiva da imagem da letra ao corpo. Uma grandeza enigmática se reverbera na orquestração da composição de Liszt, e esclarece um tipo de marca histórica na música clássica do século XIX, que se estende até os dias de hoje.

Nesse caso, vale compreendermos quais são as posições que esta Sonata de Liszt enuncia. Segundo a análise de F. d. Leone (2015), esta Sonata a) é um retrato musical da lenda de Fausto e sua relação com Mefistófeles; b) traz em seu tema um reflexo do divino e do diabólico, baseado tanto na Bíblia quando no Paraíso Perdido de Milton; c) trata de uma alegoria do Jardim do Éden e toca na questão da queda do homem, com a presença de Lúcifer, a Serpente, Adão e Eva. Entendemos, assim, que a regularidade discursiva do espaço sonoro da Sonata se aglutina à materialidade corporal das visualidades na abertura, a ponto de esse espaço musical clássico se transfigurar no próprio corpo das letras e ascender seu lugar de espaço sonoro a corpo sonoro. Daí a Sonata de Liszt configurar mais um eixo do corpo-espaço para a reafirmação do monstruoso, da transgressão às leis da natureza, do demoníaco, um corpo-espaço discursivo que quer refutar uma realidade bem presente que vai se mostrar sob que condições "The Black Cat" circulou naquele momento. Trata-se, assim, do corpoespaço enquanto saber histórico que assujeita ao suporte cinematográfico uma morfologia corporal em suas extensões horroríficas, anunciando um tipo de desmantelamento social, cuja atualidade é o abalo da vida econômica e seus efeitos nos Estados Unidos. 
Pensando a partir das superfícies de emergência, não podemos deixar de considerar que "The Black Cat" de Ulmer é um filme entre duas grandes guerras, a Primeira Guerra Mundial, de 1914 a 1918, e a Segunda, de 1939 a 1945. Em particular, a película é produzida e lançada durante o período da Grande Depressão nos Estados Unidos, período de crise de recessão econômica que tomou toda a década de 1930. Sob essas condições de possibilidade o espectro da imagem do gato preto na abertura e ao longo do filme identificam um campo de memória de desolação social que exigia dos sujeitos daquele momento se readequarem a modos de vida diferentes daqueles até então praticados. O sombrio gato preto e o aspecto insólito de sua aparição assombra as vidas dos estadunidenses e requer que recriem novas vidas, tal qual a conhecida máxima das sete vidas que um gato teria.

O corpo abjeto em sua visualidade não tarda a aparecer nos créditos, firmando-se por meio de um gato que avança pelo lado esquerdo da tela, dado a ver por meio de uma grande sombra preta com os contornos do felino. O campo de memória histórico sobre o gato preto, constituindo uma aura de mau agouro que lhe foi injustamente imputada historicamente, se encadeia ao excesso letal da conduta desmesurada dos personagens e as relações de seus corpos com os espaços. Tal visada se inicia com o próprio espaço da tela, ali, em agrupamento ao corpo, também um espaço abjeto, que é, então, preenchido com o corpo do gato preto. Finalmente, assim se compõe o corpo-espaço abjeto nos créditos de abertura, fazendo imergir as condições de possibilidade da atualidade que impulsionou sua circulação.

Essa trajetória das audiovisualidades em "The Black Cat" caracteriza sua individualidade como filme em relação ao conto de Poe e é marcadamente tornada visível na abertura com a imagem da enunciação Suggested by the immortal Edgard Allan Poe Classic, que garante os deslocamentos da literatura para o cinema e informa sobre a verificação de uma realidade que singularizará a unidade discursiva de cada objeto, seja literário, seja fílmico.

\section{A unidade discursiva}

O corpo-espaço, assim como outras unidades discursivas, configura-se como um "nó em uma rede": granos que no circuito discursivo fazem o analista se deter para observar sua composição. Destacamos que cada nó vai produzindo um tipo de regularidade específica. Ali, diante daqueles nós, o analista se depara também com um 
enunciado que "tem sempre margens povoadas de outros enunciados" (FOUCAULT, 2008, p. 110). Somam-se, assim, às diversas regularidades produzidas por cada nó uma gama de formações dispersas ao objeto. Com isso, vemos que o movimento que percorre o corpo-espaço é aquele ensinado por Michel Foucault no que tange a regularidade e dispersão do enunciado. $\mathrm{O}$ ponto em comum dessa visada entre nó discursivo e o povoamento de suas margens é o que entendemos como campo de memória. Um largo campo de batalha no qual o corpo-espaço abre um território para a entrada de fatos e fenômenos históricos que eletrizam o circuito do corpo-espaço. Em suma, há sempre um ponto específico, bem delimitado, a partir do qual transitam uma porção de outras formações no interior de um grande campo que chama e denúncia a memória de tempos do passado e do presente.

No conto "O gato preto" de Edgar A. Poe, o narrador, levado por um sentimento que ele não consegue descrever, fica possuído e deseja matar o seu gato, porém acaba matando a sua mulher, pois, com ódio pelo fato de ela tê-lo impedido de enterrar o machado no gato, acaba enterrando esse objeto no crânio dela, que sempre fora tão doce e compreensiva com ele, mesmo nos últimos tempos, nos quais sofria uma mudança enorme de caráter e atitudes. Um corpo é morto no lugar de outro corpo, mas o que fazer com esse corpo-espaço? Ocultá-lo em outro espaço: "Finalmente, detive-me no que considerei um expediente bem melhor que qualquer um destes. Decidi emparedá-lo na adega, como se diz que os monges da Idade Média emparedavam suas vítimas" (POE, 2001, p. 299). Corpo e espaço se convertem em corpo-espaço uma vez que são os responsáveis por fazer brilhar aquela constelação discursiva. Esse corpo-espaço morto e emparedado da mulher, enquanto unidade discursiva, recolhe de outros corpos emparedados sua composição, que é, pois, heterogênea. Aqui, se instala um nó na rede bastante significativo para o compósito corpo-espaço, demonstrando uma regularidade entre morte e emparedamento, não sem antes se abrir para uma dispersão de fatos.

Consideremos, então, que o próprio narrador define o corpo morto de sua mulher como um lugar discursivo que dialoga com outros corpos mortos, os dos monges da Idade Média. Ademais, podemos agregar a essa relação entre esses corpos-espaços outros corpos-espaços igualmente emparedados, como os das Virgens Vestais na Roma da Antiguidade. Elas eram moças puras, consideradas perfeitas física e moralmente, oriundas de famílias respeitadas, que tinham por missão guardar o celibato e conservar acesa uma chama sagrada nos templos de Vesta, deusa benfeitora da família e da casa. Vejam, portanto, que o movimento, neste momento, é de alargamento de um campo de 
memória que retoma e recita um momento histórico alhures à constituição da formação do corpo-espaço.

No quadro desse campo de memória da antiguidade romana, os corpos-espaços das virgens não tinham uma função para si, mas para o outro, assim como a mulher do narrador do conto em tela neste ensaio, cujo corpo-espaço existia em função do corpoespaço do marido. Se a Virgem Vestal não cumprisse o celibato ou descuidasse da chama acesa e do templo de Vesta, era logo emparedado. Tal narratividade faz o nó da rede com sua regularidade encontrar uma dispersão histórica que ilumina um campo de memória na narrativa visando dizer e enunciar a posição do corpo-espaço. Na dispersão entre esses corpos-espaços há, então, uma dada regularidade, que é da ordem da transgressão e do sagrado. Desse modo, o movimento teórico nó na rede/ regularidade margens povoadas/dispersão - campo de memória é que configura o espaço para a emergência do objeto do discurso.

Sob essa perspectiva, o corpo-espaço da mulher realiza uma transgressão ao colocar-se entre o corpo-espaço do marido e o corpo-espaço do gato e por esse motivo recebe a penalidade; entretanto, como uma reverência ao fato de o corpo-espaço da mulher tê-lo sempre servido, o corpo-espaço do marido decide efetivar o acontecimento morte seguindo um ritual que de certa forma torna o corpo-espaço da mulher um corpoespaço sagrado. Essa relação se efetua por meio de um imbricamento entre a interioridade e a exterioridade do corpo-espaço, porquanto o corpo-espaço da mulher se torna sagrado por sua relação com o espaço externo no qual é inserido/escondido: atrás das paredes da adega, recitando um ritual tão perto e tão longe dele. Assim, a unidade discursiva dos corpos-espaços e constroem pelas regularidades e pelas dispersões, pelo fora (sua relação com outros espaços) e pelo dentro (sua relação consigo), pelo dito e pelo não-dito.

Os entornos das unidades do discurso, como estamos acompanhando, dá lugar a uma produção das descontinuidades do discurso, ao mesmo tempo em que se funda sobre alguns limites para compor o campo discursivo do corpo-espaço. É a análise deste campo discursivo que estamos empreendendo e que propõe uma conversão sobre a singularidade de formas de enunciação sobre o sujeito que estão em engajamento e coexistência com espaços heterogêneos. O trancafiamento dado a ver no corpo-espaço se constitui no filme desde seu início em três momentos.

Primeiro. O jovem casal em lua de mel está dentro do compartimento de um trem, lugar pequeno, fechado, cujas saídas são mostradas por uma porta que se abre e se 
fecha à direita do quadro, e a janela que liga ao mundo exterior, à esquerda. Estas linhas de separação do sujeito, são reforçadas com a chegada de Vitus, que ocupará um lugar naquele compartimento. As imagens depois da chegada de Vitus, colocam-no entre o casal, que são vistos por nós espectadores de costas, o que nos coloca de frente com Vitus. Nessa composição dos corpos naquele espaço, Vitus se situa bem no meio do casal, entre eles. Dessa forma, há um dupla separação dada pelo acontecimento do corpo-espaço: corpos encerrados na cabine do trem, separados do mundo lá fora, e o corpo de Joan, separado do marido, e sozinha no claustro que a espera. Essa intervenção do corpo de Vitus no espaço opera também uma intrusão vital na aliança entre o casal, desestabilizando o corpo-espaço matrimonial.

Segundo. O enclausuramento da jovem esposa já anunciado será reiterado na passagem do trem para o ônibus que os levaria a seu destino de lua-de-mel. Entre o intervalo de um para o outro, as portas dão para paredes, fundos de planos que justapõem os personagens ao início de um longo emparedamento no filme. Dentro do ônibus, as visualidades são bem marcadas pelo fechamento das cortinas das janelas do ônibus e também de sua porta de entrada. O ônibus é mostrado em intericonicidade (COURTINE, 2013; MILANEZ, 2015) sob a morfologia de uma caixa fechada para os corpos, retomando a memória de um caixão gigante. A interrupção terá mais um momento atrelado ao corpo-espaço da mulher. O ônibus sofrerá um acidente, e Joan ficará separada de seu marido pela inconsciência que a toma. Fixa-se, com isso, um corpo-espaço do claustro.

Terceiro. Há um entrosamento, um tipo de orquestração entre os corpos dos personagens e a moderníssima casa de Poelzig. Os corpos ali se encaixam como peças de um quebra-cabeça, cada um em seu lugar bem delimitado, andando em espaços rígidos e muitos fechados. Desde a chegada de Peter e Joan à casa, as portas têm destaque nas tomadas dos quadros e na sequência dos planos. Ao longo do filme todo os personagens passam por portas de correr, que se fecham atrás deles. Portas que se abrem e revelam o personagem inusitadamente são uma constante. Portas que ligam a cômodos inesperados. Largas escadas ou uma escada em caracol fina e longa pelas quais os personagens sobem e descem. O ambiente arquitetônico da casa é de linhas retas, geométrico, em simetria com o corte de cabelo de Poelzig, com a retidão de seus ombros e o recorte de suas roupas. O engenheiro da Casa traz em sua morfologia corporal o cálculo arquitetônico da construção em sua anátomo-biologia. Estabelece-se, portanto, mais uma vez, a evidenciação do corpo-espaço, em intericonicidade, que faz 
da casa um corpo e do corpo uma casa de horror. As linhas da regularidade discursiva produzem uma unidade do discurso marcado pelo heterogêneo e configuram um campo de memória dentro ainda do quadro dos contos de terror de mistério de Poe. A casa em The Black Cat remonta ao mesmo tipo de discurso materializado em "A queda da casa de Usher", que se desdobrou também no filme, "A queda casa de Usher", de Roger Corman, 1960 (MILANEZ, 2012). A unidade do discurso que trata em constelação os dois filmes e os contos de Poe apresenta ao mesmo tempo uma "materialidade repetível" (FOUCAULT, 2008, p. x) e o atravessamento de intericonicidades cinematográficas: o sujeito moral atrelado ao espaço, ou seja, corpos-espaços da decadência, da destruição, do desmoronamento dos espaços e dos corpos que os abrigam, o corpo-espaço de um emparedamento moral que não resistirá à queda.

\section{Composição utópica e heterotópica}

Esse corpo-espaço é atravessado, constituído e clivado por utopias e heterotopias, é um lugar em permanente transformação. A linha que separa a utopia da heterotopia é muito tênue; assim como Gilles Deleuze e Félix Guattari (1997) afirmam que os espaços lisos não param de estriar e os estriados não param de alisar, podemos afirmar que a linha que separa os espaços utópicos dos espaços heterotópicos é extremamente imperceptível, não formando um limite entre essas duas espacialidades, mas ume fronteira. Entendemos, aqui, a noção de fronteira com base em Cássio Hissa, que esclarece o quanto os limites são voltados para dentro e as fronteiras para fora. E, nesse sentido, as fronteiras são mais porosas do que os limites: "O limite estimula a idéia sobre a distância e a separação, enquanto a fronteira movimenta a reflexão sobre o contato e a integração" (HISSA, 2006, p. 34). Assim são as utopias e as heterotopias, porque os corpos-espaços não são única e exclusivamente utópicos ou heterotópicos, mas essas espacialidades se intercambiam, se movimentam e se integram nos corpos.

Michel Foucault ensina, em "O corpo utópico", que nosso corpo (e podemos dizer: nosso corpo-espaço) é uma topia implacável (FOUCAULT, 2013, p. 7), pois dele não podemos nos desgarrar, por isso ele é comparado, como esse lugar de invólucro, a uma concha, a uma gaiola, a uma grade e à pele. O meu deslocamento implica o deslocamento do meu corpo-espaço. Ele seria, pois o contrário de uma utopia; no entanto, eu posso transformá-lo em uma utopia à medida que eu o rasuro, ou mesmo o apago, transfigurando-o, seja por meio, por exemplo, de uma máscara, seja pela maquiagem, ou por tatuagens, ou bijuterias. Nosso corpo-espaço é lugar de 
transformação, por isso um "corpo incorporal" (FOUCAULT, 2013, p. 8). Na medida em que eu o transformo pela utopia: "um lugar onde eu teria um corpo sem corpo, um corpo que seria belo, límpido, transparente, luminoso, veloz, colossal na sua potência, infinito na sua duração, solto invisível, protegido, sempre transfigurado" (FOUCAULT, 2013, p. 8). Entretanto, quando utopizamos nosso corpo-espaço, com uma maquiagem, por exemplo, podemos afirmar que o colocamos em "outro lugar", em uma heterotopia; logo, a todo o momento, experimentamos acontecimentos que nos fazem, em nossas utopias, experimentar outras posições, outros lugares. Nossas vestimentas também projetam nossos corpos-espaços para espaços mesmos ou para espaços outros, elas dizem sobre nós, elas enunciam-se e enunciam-nos. O que o nosso corpo-espaço diz sobre nós? Quais os sentidos que dele emanam e aderem às coisas ao redor?

No conto de Poe temos um gato, Plutão, que a princípio é amado pelo seu dono, o narrador, mas este começa a modificar-se de um momento a outro, passando a beber em demasia, a não cuidar dos animais, a ter ojeriza por eles, e a ser ríspido com a mulher, até o momento em que, numa noite, ele chega embriagado e arranca um dos olhos do corpo-espaço do gato, desfigurando-o. Noites depois, mais uma vez transfigurado pela bebida, o homem enforca o gato, colocando seu corpo-espaço desfigurado no ramo de uma árvore em frente à sua casa. Isso aconteceu na mesma noite em que sua casa pega fogo. Somente uma parede fica de pé. O homem aproxima-se para olhar melhor a parede intacta e nela vê: "como se gravada em baixo-relevo sobre a superfície branca, a figura de um gato gigantesco. A imagem fora reproduzida com uma nitidez verdadeiramente maravilhosa. Havia uma corda ao redor do pescoço do animal" (POE, 2001, p. 296, grifos do autor citado). Esse corpo-espaço decalcado na parede seria uma projeção do corpo-espaço do animal? Pois até há uma hipótese aventada pelo narrador:

alguém devia ter cortado a corda que prendia o animal à árvore e o lançara por uma janela aberta dentro do meu quarto. Isto fora provavelmente feito com o propósito de despertar-me. A queda de outras paredes tinha comprimido a vítima de minha crueldade de encontro à massa de estuque, colocado de pouco, cuja cal, com as chamas e o amoníaco do cadáver, traçara então a imagem tal como a vi. (POE, 2001, p. 297)

Ou a projeção do corpo-espaço decalcada do gato seria uma projeção utópica do dono do animal, que, depois de matar o gato, arrepende-se de tal ato tão cruel e, para tentar consertar seu ato - ou mesmo como uma forma de obsessão -, projeta no decalque a forma do corpo-espaço do gato como se ele ainda fosse o seu Plutão? 
Contudo, passado algum tempo, o homem encontra, em um bar, outro gato:

Era um gato preto, um gato bem grande, tão grande como Plutão, e totalmente semelhante a ele, exceto em um ponto. Plutão não tinha pelos brancos em parte alguma do corpo, mas este gato tinha uma grande, imprecisa mancha branca cobrindo quase toda região do peito. (POE, 2001, p. 297)

O desejo do homem de ter seu gato de volta era tão grande que ele enxerga no corpo-espaço do segundo gato formas similares às do primeiro gato. A expressão "totalmente semelhante" reforça a leitura que o homem faz do corpo-espaço daquele gato. É como se o corpo-espaço desse segundo gato fosse um lugar sem lugar, uma utopia, um corpo incorporal, e nele pudesse ser projetada a imagem do desejo, pudesse ser feita a leitura mais conveniente e pudesse ser projetado outro corpo. Em função disso, então, podemos compreender que do corpo-espaço do segundo gato temos a projeção do outro, de outro espaço; logo, desdobra-se também como uma heterotopia.

O desejo do homem de ter seu gato de volta por intermédio do corpo-espaço de outro gato é confirmado, porque somente no segundo dia é que ele vai perceber que também o outro não tem um dos olhos. Esse fato, tão importante, passa despercebido, porquanto o principal, naquele primeiro dia, era enxergar no gato o outro gato, o que ocorre em função do tamanho grande do animal. Depois que descobre o olho que falta, transfere para o corpo-espaço do segundo gato o ódio que tinha do primeiro gato, o que se intensifica quando percebe que a mancha branca que havia marcada no corpo-espaço do segundo gato tinha o formato de uma forca. Forca que teria enforcado o primeiro gato? Ou forca que seria o futuro do narrador por ter assassinado sua mulher? No primeiro caso, essa marca corpórea-espacial seria a reminiscência de um fato para fazêlo reviver a cada mirada de olhos sobre a mancha. No segundo caso, a marca corpóreaespacial seria uma prolepse, um indício de acontecimentos futuros. Esse corpo-espaço que se desdobra pode ser entendido como o lugar do duplo, que a um só tempo é projeção do mesmo e do diferente, de utopias e de heterotopias.

O gato preto é incontestavelmente uma formação rugosa e espaço de rupturas e desdobramentos também no filme. Em um primeiro momento, cabe entendermos que a produção heterotópica é fortemente marcada pela constituição de uma intericonicidade. A intericonicidade, como sabemos, trata da repetição de uma morfologia corporal indissociável da historicidade que faz certo corpo emergir. $\mathrm{O}$ aparecimento desse outro corpo, transformado, transmutado, decodificado em outras histórias é o espaço de passagem do corpo em progressão para o nascimento de um corpo outro, como 
entendemos a questão das "heterotopias biológicas" para Foucault (2013, p. 22). Compreendemos, assim, a heterotopia biológica como um eixo do corpo-espaço, aquilo que faz corpo e espaço transcenderem e formarem um novo objeto de discurso. Esse é o caso do gato preto em "The Black Cat".

$\mathrm{O}$ gato preto no filme aparece em momentos bem específicos. O mais relevante agora seja talvez apontar sequências em que o gato preto tenha por finalidade criar o efeito de uma presença sombria no espaço. O gato preto aparecerá em horas inusitadas e de crise. Inusitadamente, mas não aleatória, o gato preto aparece em sequências que no seu encadeamento mostram mulheres enclausuradas, tais quais Joan, Karen, a esposa de Poelzig e a filha de Vitus, e as mulheres mortas guardadas em caixões de vidro. Nesse sentido, o gato preto antecipa e afirma a presença do enclausuramento das mulheres dentro da casa. $\mathrm{O}$ corpo do gato precede o corpo das mulheres e reivindica para si o espaço prisional no qual elas se encontram. Dois níveis de corpos se encontram aí em um mesmo espaço. Trata-se de um corpo-espaço cuja heterotopia é marca da transformação do espaço doméstico convertido em masmorra para belas donzelas.

No que se refere ainda à heterotopia do biológico, encontraremos várias vezes Poelzig acariciando o gato preto em seu colo. Nesses planos, a relação é sempre de controle sobre as mulheres. O efeito que se cria é que a força, o mistério e a dominação do gato preto se transpusessem para Poelzig. O corpo a corpo entre o gato preto e Poelzig, que lidera e coordena a movimentação dentro do espaço da casa, compõem o corpo-espaço da coerção e da sujeição dos outros personagens. Isso parece ser possível uma vez que o domínio espacial de Poelzig na casa seja tão furtivo e sagaz, tão sorrateiro e certeiro, tão vigilante e atacante como o de um gato. O corpo-espaço que deflagra Poelzig é o mesmo do gato preto. Há um intercambiamento entre os dois. A heterotopia biológica fará deles uma única marca. O cabelo de Poelzig, o seu corte, e o modo de pentear, em intericonicidade, retomam a constituição morfológica da pelagem de um gato. Com isso, a discursividade do gato dentro do filme também é incorporada pela personagem. O gato, dono dos espaços, comandante dos territórios, se transfigura na figura horrorífica do personagem de Boris Karloff, a materialização do corpo-espaço de um obscurantismo sádico, perverso, cruel.

Como vimos, o gato preto e de Poelzig se equivalem em corpo e espaço. Reconhecer a equivalência dessas duas instâncias pode ajudar a compreender outros desdobramentos heterotópicos de um corpo-espaço. Um elemento menos evidente na torção desta noção é quando, em um filme, a letra perde seu posto de grafia para 
assumir seu posto gráfico, mudando de espaço escriturário para os domínios do visual, da imagem. É o que veremos na sequência em que a tela é preenchida por uma página dos Rites de Lucifer, que Poelzig lê antes que cheguemos aos rituais satânicos do final do filme. Dessa forma, a letra renascida em imagem, heterotópico, ocupa o espaço da tela em corpo-espaço dotado da nervura da alma de Poelzig e dos canteiros da arquitetura sombria daquela morada: um corpo-espaço que se deflagra do desvio que a letra pode assumir, mostrando-nos que não há estabilidade ou cristalização para as imagens em movimento, mas antes de mais nada, uma possibilidade incrível de sempre ter outra perspectiva, outra posição, outro sentido.

\section{Realidade e real: o sistema de veridicção}

A abordagem do entendimento da realidade em um quadro para o real encontrase aqui direcionada para o corpo-espaço. Compreendemos que o discurso elabora as condições do existência do real em relação com os jogos de verdade. Esse corpo-espaço se elabora discursivamente sob as condições de existência do real e seu modo de se relacionar com a realidade. Portanto, realidade e real não tratam da mesma questão, mas produzem no discurso materialidades simultaneamente. A relação da noção de realidade a uma dada materialidade já se encontra planteada em "A ordem do discurso" (1999, p. 8): “inquietação diante do que é o discurso em sua realidade material de coisa pronunciada ou escrita" E, como Foucault (2010, p. 208) ensina, a "realidade [...] através da qual a veridicção filosófica vai se manifestar como real é o fato de que ela se dirige, que ela pode se dirigir, que ela tem coragem de se dirigir a quem, exerce o poder". A realidade relaciona-se a uma experiência (FOUCAULT, 2008), ou seja, seria o real deflagrado, materializado em uma possibilidade de existência. Enquanto materialidade do real, a realidade ganha várias nuanças e desencadeia sentidos diversos, ou seja, um mesmo real projeta-se em realidades distintas, assumindo perspectivas variadas como um caleidoscópio. Desse modo, a realidade é um tipo de experiência de si que marca o sujeito e o real está no campo da verdade e conduz a um sistema de veridicção para o sujeito.

Nosso foco, por ora, é engendrar sobre a manifestação da realidade nas formas do real e certos sistemas de verdade. Para tanto, recorremos a Foucault em "Subjetividade e verdade", ao afirmar que não é correto pensar que se tal verdade é afirmada é porque essa verdade é real, deve-se adotar um sentido inverso e, dessa forma, levantar algumas questões, como: 
Sendo o real o que ele é, quais foram as condições improváveis, as condições singulares que fizeram, com relação a esse real, um jogo de verdade poder surgir, certamente com suas razões, suas necessidades, mas suas razões e suas necessidades que não são simplesmente o fato de as coisas em questão existirem? (FOUCAULT, 2016, p. 198).

A partir desse raciocínio, Foucault considera que uma forte correspondência entre a verdade e o real. Em “Aulas sobre a vontade de saber" (2014), Foucault ressalta a importância de considerar-se a verdade aos sujeitos e seus modos de enunciar, visto que, se uma verdade é manifestada isso ocorre em decorrência de uma defesa desses sujeitos em relação às suas verdades enunciadas. Podemos dizer, a partir desse mirante, que um jogo de veridicção norteia a produção do real, dando-lhe forma e sentido. Essa ideia também se encontra articulada em sua Aula de 16 de fevereiro de 1983, no Collège de France, no curso intitulado "O governo de si e dos outros": "Interrogar-se sobre o real da filosofia [...] é se perguntar o que é, em sua própria realidade, a vontade de dizer a verdade, essa atividade de dizer a verdade, esse ato de veridicção" (FOUCAULT, 2010, p. 208).

Portanto, o real (logo, o corpo-espaço real) irrompe por meio de regimes de veridicção que assinalam vontades de verdade determinadas por regimes de poderes. As vontades de verdade apoiam-se no jogo verdadeiro/falso e em torno desse jogo são produzidas as contingências históricas, as possibilidades de experiência, ou seja, as possibilidades de real. Para reconstituir-se uma história do real, é preciso, pois, desvelar a emergência dos jogos de verdade, dos regimes de veridicção, das vontades de verdade. Obviamente, como Foucault esclarece, em "Subjetividade e verdade", não se trata do fato de que o real é construído por uma verdade, mas por um jogo de verdadeiro e falso, por um jogo de veridicção que transmuda o real, transformando-o continuamente. $O$ real é movente. A relação entre subjetividade e verdade desencadeia o efeito dos regimes de veridicção e constrói os reais a que temos acesso, dentre eles o nosso corpo-espaço. Vejamos algumas possibilidades da interrelação entre real, verdade, corpo e espaço para a constituição da noção de corpo-espaço.

Pode-se pensar que todo o enredo do conto "O gato preto" desenvolve-se por meio dos regimes de veridicção traçados pelo narrador-protagonista. Ele oscila entre crer que o corpo-espaço do gato preto é terrífico e lhe causa o mal, e, em outros momentos, crer que esse corpo-espaço é apenas insignificante para o seu destino; oscila entre crer que há dois corpos-espaços de dois gatos que o perseguem e crer que há 
apenas um corpo-espaço ressurgido do inferno para persegui-lo. Todas essas oscilações de verdades-de-si compõem a rede de um jogo de verdadeiro-falso, de vontades de verdades que o conduzem para um único objetivo: matar o corpo-espaço que o atormenta, e, quando tenta cumpri-lo, acaba matando o corpo-espaço de sua mulher. Seria um desejo retido (um dizer só a si mesmo a verdade) e só concretizado com a projeção da morte de um outro corpo-espaço nominadamente maldito?

Em "The Black Cat" os tecidos do corpo-espaço apontam para a formação de um quadro da mulher no interior de um dispositivo de aliança no qual elas servem a uma estrutura patriarcal, o real das redes do matrimônio. Joan entrará ao início do filme na mansão Art Deco de Poelzig já desacordada, passará grande parte da trama em um quarto, aprisionada, atordoada, mais especificamente, sobre uma cama, à espera da noite de núpcias que não se concretiza. A virgindade, materializada na leitura das imagens das letras do "Rite of Lucifer", se refere às donzelas vestidas de branco, tal qual o figurino de Joan dentro da casa. Não obstante, Karen, também sempre fechada em seu quarto, é submetida à hipnose e ao controle de Poelzig. Vestida de branco, como também as enclausuradas dos caixões de vidro, é fadada ao silêncio, sem direito a falar ou agir.

Os corpos das mulheres estão presos ao espaço que as encarcera, normativa para o real dos corpos-espaços subjugados a um estatuto social. Já não sabemos mais quem é o protagonista nesse jogo do real, cujas metades se completam em corpo-espaço para o apagamento da mulher. Não obstante, as mulheres reagem, mas sob a égide da histeria de seus corpos lânguidos e caídos ao chão ou por meio de gritos, muitos gritos, frequentes, seguidos de apavoramentos ou desmaios. Que real essas audiovisualidades deixam transparecer? Tal atitude descaracteriza a possibilidade de assumirem atitudes produtivas ou gestões aceitáveis. O real convoca um espaço vocal dos berros que atribui e conforma a histerização dos corpos, convergindo para uma história da mulher cuja pedagogia se centra no casamento como meta e ponto de equilíbrio social. Senão, sua virgindade tão desejada caberia à perversão de rituais satânicos, colocando a mulher ao lado da tão cansativa e há muito desgastada imagem de um real sobre Eva, a diabólica, a maldita, responsável pela queda do paraíso dos idiotas.

O corpo-espaço aí tem suas superfícies históricas dadas, suas condutas previstas. O espaço da história matrimonial se aglutina ao corpo e sexo castos da mulher. A retomada do amor romântico e sua visada sobre Romeu e Julieta são ainda uma aposta importante de Ulmer na direção da questão matrimonial, tanto que a Abertura de Romeu 
e Julieta de Tchaikovsky é a canção de fundo para Joan e Peter. Disso tudo brota o real do corpo-espaço prisional das condutas para a mulher face a um sistema de veridicção baseado na criação, na procriação e no matrimônio (FOUCAULT, 2019). O real do corpo-espaço não escapa à verdade de sua época, atravessa o corpo social e abre o campo para o espaço histórico invadir o sujeito. O real é a verdade e os saberes que o corpo-espaço promove.

\section{REFERÊNCIAS}

CHEVALIER, Jean; GHEERBRANT, Alain. Dicionário de símbolos. Tradução de Vera da Costa e Silva, et al. Rio de Janeiro: José Olympio, 1990.

COURTINE, Jean-Jacques. Decifrar o corpo: pensar com Foucault. Tradução de Francisco Morás. 1ªed. Petrópolis: Vozes, 2013.

DELEUZE, Gilles; GUATTARI, Félix. Mil Platôs: capitalismo e esquizofrenia - vol.5. Tradução de Peter Pál Pelbart e Janice Caiafa. Rio de Janeiro: Ed. 34, 1997.

FOUCAULT, Michel. A ordem do discurso: aula inaugural no Collège de France, pronunciada em 2 de dezembro de 1970. Tradução de Laura Fraga de Almeida Sampaio. 15 ed. São Paulo: Loyola, 1996.

FOUCAULT, Michel. A Arqueologia do Saber. Tradução de Luiz Felipe Baeta Neves. $7^{\mathrm{a}}$ ed. Rio de Janeiro: Forense Universitária, 2008.

FOUCAULT, Michel. O Governo de Si e dos Outros: Curso no Collège de France (1982-1983). Tradução de Eduardo Brandão. São Paulo: WMF Martins Fontes, 2010.

FOUCAULT, Michel. O corpo utópico, as heterotopias. Tradução de Salma Tannus Michail. São Paulo: n-1 Edições, 2013.

FOUCAULT, Michel. Aulas sobre a vontade de saber: Curso no Collège de France (1970-1971). Tradução de Rosemary Costhek Abílio. São Paulo: WMF Martins Fontes, 2014.

FOUCAULT, Michel. Subjetividade e Verdade: Curso no Collège de France (19801981). Tradução de Rosemary Costhek Abílio. São Paulo: WMF Martins Fontes, 2016.

FOUCAULT, Michel. História da Sexualidade IV: As Confissões da Carne. Tradução de Miguel Serras Pereira. Relógio D’Água, Lisboa, 2019.

GAMA-KHALIL, Marisa Martins; MILANEZ, Nilton (Orgs.). Personas insólitas: conjunções espaciais e temporais na composição de personagens no insólito ficcional. Rio de Janeiro: Dialogarts, 2018.

HISSA, Cássio Eduardo Viana. A mobilidade das fronteiras: inserções da geografia na crise da modernidade. Belo Horizonte: Ed. UFMG, 2006.

LEONE, F.D. Overview and Analysis of the Liszt Piano Sonata in B Minor, S. 178. Musica Kaleidoskopea, 2015. Disponível em: $<$ https://fdleone.com/2015/07/09/overview-and-analysis-of-the-liszt-piano-sonata-in-bminor-s-178/> Acesso em: 15 Jun. 2020. 
MILANEZ, Nilton. A Casa de Usher de Roger Corman: o campo de memória e o cromático-discursivo no discurso fílmico. In: GAMA-KHALIL, Marisa Martins; GARCIA, Flávio; VOLOBUEF, Karin. (orgs). Revista R. Letras. \& Letras. Uberlândia-MG, v. 28 n.2, jul./dez. 2012, p. 579-590.

MILANEZ, Nilton. Intericonicidade: da repetição de imagens à repetição dos discursos de imagens. Acta Scientiarum. Language and Culture (Impresso), v. 37, p. 197-206, 2015.

MILANEZ, Nilton. Audiovisualidades. Elaborar com Foucault. Londrina: Eduel; Guarapuava: Ed. Unicentro, 2019.

POE, Edgar Alan. Ficção completa, poesia \& ensaios. Tradução de Oscar Mendes e Milton Amado. Rio de Janeiro: Nova Aguilar, 2001. 